\title{
NEUROMARKETING AND THE DECISION-MAKING PROCESS OF THE GENERATION Y WINE CONSUMERS IN THE SLOVAK REPUBLIC
}

\author{
Jana Němcová, Jakub Berčík
}

\begin{abstract}
In recent years, interest in scholarly research on buying behaviour of Generation $Y$ has grown. However, studies are mainly realized abroad and many of them deal with this issue in general. The purpose of this paper is to identify the factors influencing the decision-making process of the Generation Y customers in the selection of wine in the Slovak Republic. A total of 21 respondents participated in the survey. Eye-tracking and a questionnaire were selected for research. For processing and evaluating the eye-tracking research, the Gazepoint Analysis UX Edition software and Microsoft Excel were used. For statistical data analysis, the Kruskal-Wallis test and Spearman's non-parametric test were performed. Based on the results of the questionnaire and the testing, a label was the most important factor. Differences were noted at the moment of examining the information on a label. The most important factor determined by the questionnaire survey was variety, or vintage year, but by using measurement, the most important factor was label design. With regard to bottle shape, the most preferred was the Bordeaux type of bottle. Testing was carried out in laboratory conditions that only simulated the real selection of wine. This could have caused the difference between conscious decision-making and unconscious visual attention. Therefore, in the future, it is recommended to carry out similar research using a mobile eye camera to realize the test with real wine bottles. It is also assumed to involve other methods to obtain information about real attention of the tested probands. The presented research provides information for winegrowers and merchants who can improve their products and communicate effectively with customers. Findings are particularly beneficial because this research is among the first carried out in this area and it was not based only on conscious participation of respondents, but also on unconscious perception, because a deeper understanding of unconscious influences, that shape consumer's decision, helps to better understand consumer's behaviour.
\end{abstract}

Keywords: consumer behaviour; decision-making process; Generation Y; wine factor; Slovak Republic

\section{INTRODUCTION}

Many marketing specialists have been dealing with consumer behaviour for a long time to get the best possible placement of their products on the market. Schiffman and Wisenblit (2015) describe consumer behaviour as a set of consumer activities while searching for, purchasing, using, evaluating, and disposing of products or services that are expected to meet their needs. Businesses need to know the answers to questions such as how and why consumers buy and consume in order to develop their products and effectively communicate with customers (Szmigin and Piacentini, 2015). The key point of marketing is the focus on the customer and his decision-making. Understanding the processes relating to these decisions is crucial to establishing a policy (Sethna and Blythe, 2016). The consumer decision-making process consists of many theoretical constructs and is often complicated, as stated by Roe and Bruwer (2017). According to Tomek and
Vávrová (2011), no company on the market knows in advance when and whether buyers will demand its products at all. In order to be successful sellers on the market, they must ensure that their activities meet the wishes and needs of target customers. Based on this, they must understand the mechanisms and determinants that influence the purchasing decisions of customers. Understanding the forecast of consumers' and purchasing behaviour is one of the main goals of marketing specialists.

Today's market has changed significantly. Sale is more difficult, in part due to more sophisticated buyers who have more information, more intense competition, a longer sales cycle, and increased resistance to traditional techniques. However, a modern approach using neuromarketing helps to create effective marketing strategies, thereby increasing motivation to purchase, the number of concluded contracts and the multiplication of 
revenue (Berčík et al., 2016). Neuromarketing is a newly emerging discipline discovered in 2002 that connects consumer behaviour with neuroscience. It provides modern methods for direct mind detection without the need for demanding cognitive or conscious participation (Morin, 2011). Currently, neuromarketing is used for the commercial exploitation of neuroscience knowledge and tools which help companies to better understand consumer reactions to the various communication efforts connected with brands, products or services (Ramsøy, 2015).

There is a large amount of wine products for retail and it is very difficult for the consumer to decide what to buy. However, there is no united approach or theory of wine consumer decision-making that describes consumer characteristics, product involvement, etc. Lockshin and Corsi (2012) add that a large number of published articles show growing popularity of wine and interest in consumer behaviour research, and provide a detailed analysis of articles divided by theme in their publication. According to Babin and Harris (2016), consumers make decisions for the purpose of getting something of value and quality to improve their lives. Companies then try to offer consumers products and services, including experience, that will bring them such value.

Anchor and Lacinová (2015) mention that, for the consumer behaviour research on the wine market, it is important to know the motives for wine drinking. Identifying the importance of wine in the consumers' lifestyle and recognizing the situations in which the consume of wines by customers facilitate the understanding of the issue of consumer purchasing decisions. According to Marinelli et al. (2014), understanding the approach of purchasing wine is an important factor for the winemaking industry. Understanding these attitudes, particularly among the younger generation, can be useful for solving the longstanding traditions of the wine region. At present, many marketers deal precisely with the needs of young people aged between 18 and 34, called Generation Y or Millennials (Schiffman and Wisenblit, 2015). In recent years, this generation has also been intensively studied in relation to the wine market (Mueller et al., 2011). In general, Generation Y is defined as the age cohort born in the 1980s and 1990s. Some authors define this segment as people who were born slightly later in time, for example Sethna and Blythe (2016) describe this generation as a generation of people born between 1981 - 2001 (aged between $17-37$ in 2018). This generation cohort has an increasing interest in wine, it is willing to pay for wine and its consumption is different from previous generations (Hall et al., 2004; Thach and Olsen, 2006). It is a very promising wine consuming segment, which will become more and more important in the future as wine consumers (de Magistris et al., 2011; Charters et al., 2011). Chrysochou et al. (2012) are inclined to think that young Generation $\mathrm{Y}$ is quickly adopting wine as its preferred drink and is therefore a consumer segment with the potential to increase the growth of wine consumption in the near future. Taking into account the differences among age groups will bring new opportunities for winegrowers and wine merchants. Also Fountain and Lamb (2011) highlight the need to promote an interest in wine among the younger generation. This results from the fact that the
Baby Boomer generation, for a long time perceived as the leading wine consumers, is ageing and, therefore, it is now necessary to pay more attention to young consumers in the wine industry. Generation $\mathrm{Y}$ is currently considered one of the largest demographic groups. However, there are also differences within generations, especially among these young people who behave very differently and therefore cannot even generalize this cohort (Bergh and Behrer, 2016). Therefore, only a narrower part of this generation has been selected for consumer behaviour research on the wine market in Slovakia, namely young people aged between $18-25$.

There are many foreign studies in which authors deal with the purchasing behaviour of Generation $\mathrm{Y}$ in relation to wine. As far as the importance of attributes is concerned, this issue was most often explored by de Magistris et al. (2011); Elliot and Barth (2012); Dlačić and Kadić-Maglajlić (2013); Stanciu and Neagu (2014); Hristov and Kuhar (2015) and Lategan et al. (2017). In the Czech Republic, the area of consumer behaviour and Generation Y is solved by Veselá and Zich (2015) who describe the effect connected to the country of origin and its influence on the consumer behaviour of the Czech and Slovak young consumers, and Velčovská (2018) who examines perception of product origin and its labelling in the context of food quality and safety among Czech, Slovak and Polish Generation Y. However, there is a lack of research applied to Generation $\mathrm{Y}$ and wine market. Scientific literature on wine Generation $\mathrm{Y}$ is very rare also in Slovakia. This study should therefore contribute to the expansion of literature on this issue.

Wine is one of the most consumed beverages and has been known in human civilization for many millennia. Besides its economic importance, it can also positively influence human health. In some European countries, a glass of wine is intrinsically linked to good food (Tariba, 2011; Brunner and Siegrist, 2011). There are many studies that confirm the usefulness of wine when consumed in low quantities. The moderate consumption of this traditional drink may have positive effects, for example, in cardiovascular diseases, diabetes, osteoporosis or neurological diseases (Artero et al., 2015; Šamánek and Urbanová, 2013).

The wine market has made significant progress over the last two decades. Both the legislation and the level of technical equipment for wine production have improved. According to The International Organisation of Vine and Wine (OIV, 2017), world wine consumption has a relatively stable character over the long term. Although there was a slight decline in wine consumption in France last year, other traditionally wine consuming countries such as Spain and Portugal notified a stable consumption. On the contrary, there was a significant increase in wine consumption in Italy. The USA also showed a growing domestic consumption and once again confirmed its excellent position on the global wine market.

The Slovak Republic is not part of the world's significant producers or consumers of wine. However, the winegrowing tradition of this country has deep roots and vine growing on the territory of today's Slovakia is connected with an interesting history. Regulation No 313/2009 divides the Slovak wine-growing region into 6 areas, namely Malokarpatská, Južnoslovenská, Stredoslovenská, 
Nitrianska, Východoslovenská and the Tokaj winggrowing area. The total area of vineyards currently stands at $10,800 \mathrm{ha}$, of which the cultivated area of vineyards represents 8,872 ha. In 2015, the total wine consumption was $80,210 \mathrm{hL}$, which was $14.8 \mathrm{hl}$ per capita. In 2016, there was a slight decrease and the consumption of wine per capita fell to $13.9 \mathrm{hL}$. The production of wine reached $310,000 \mathrm{hL}$ for the period 2016/17, but in the following year the production of wine is expected to increase to $340,000 \mathrm{hL}$. The countries with the largest import of grapes and wine to Slovakia include Hungary, Italy and Germany. On the other hand, Slovakia most often exports grapes and wines to the Czech Republic and Hungary (Meravá, 2017).

\section{Scientific hypothesis}

As mentioned above, many authors are concerned with consumer behaviour on the wine market. However, these surveys are aimed at all age groups, and thus there are few publications describing behaviour of the young generation. Therefore, this article is concentrated on the still often marginalized Generation $\mathrm{Y}$ and its decision-making process in the selection of wine in the Slovak Republic. The main objective of the article is to reveal the factors that have a crucial influence on decision-making of the Generation Y customer when choosing wine in Slovakia. The purpose of research is to identify the wine attributes by which young customers choose wines, and thus to understand their purchasing decision-making process. In relation to the hypothesis, the $p$-value $p=0.05$ was used, where we tested whether there is difference in tracking wines based on location in the image stimulus (whether it is located on the right, left or centre). Using the $p$-value $p=0.05$, we verified the dependence between first tracking and time spent.

\section{MATERIAL AND METHODOLOGY}

For this research, a neuromarketing method called eyetracking was chosen, which explores unconscious visual attention of the respondents. Specifically, the Gazepoint GP3 eye-tracker (Gazepoint Canada) with data collection frequency of $60 \mathrm{~Hz}$ was selected - the respondent was sitting in front of the computer screen and was watching the images presented. Eye-tracking testing was then completed by a questionnaire that was conducted electronically using a cloud storage service called Google Drive. For the purposes of this research, which ran from April to May 2017, the Laboratory of Consumer Studies at the Faculty of Economics and Management of Slovak University of Agriculture in Nitra was used.

Testing was attended by a total of 21 respondents who subsequently completed a questionnaire containing questions that resulted from eye-tracking testing. The aim of the questionnaire was to find information about wine preferences given consciously by the respondents. Subsequently, it was examined whether there are differences between conscious (questionnaire) and unconscious (eye-tracking) perceptions of marketing stimuli.

This research was based on the theoretical background and consultation offered by the specialist staff of the wine shop in Zlín in the Czech Republic. Before the research itself, different combinations of wine bottles had to be created, which were then professionally photographed and adjusted. Each photo contained 3 wine bottles. Variants were drawn up in combinations by brand, variety and discount, then by brand, variety and quality class, by bottle shape and by bottle that was awarded medal. Measurement included 5 photos with white wine. Prepared photos were then uploaded into the software program and were projected to the respondents in the eye-tracking testing. The factors influencing customers' decision-making in the wine selection included: colour of wine, label design, the information on a label (brand/producer, variety, vintage year, quality class of wine, wine-growing region, residual sugar content, actual alcoholic strength and nominal volume), bottle shape, bottle colour, medals, price and discounts.

Three research questions were defined:

RQ1: What are the key factors that influence conscious decision-making of Generation $\mathrm{Y}$ on the wine market?

RQ2: What are the key factors that influence unconscious decision-making of Generation Y on the wine market?

RQ3: Is there a difference between conscious and unconscious perceptions of marketing aspects when choosing wine among Generation Y?

\section{The Sample of the Respondents}

Eye-tracking was attended by 21 respondents who filled out a questionnaire immediately after the testing. The purpose of the questioning was to find the conscious answers to the questions. These were the respondents aged $18-25$ who had drunk or at least bought wine for the last 12 months. According to Noble et al. (2009), precisely this age category is an important segment in the lucrative college market. Eye-tracking was conducted using a stationary eye camera, and following filing of a questionnaire was carried out electronically using a cloud storage service called Google Drive.

As shown in Table 1 below, 11 women (52\%) and

Table 1 Sample characteristics.

\begin{tabular}{llcr}
\hline Sample characteristics & Number & \% \\
\hline \multirow{2}{*}{ Gender } & Female & 11 & 52 \\
& Male & 10 & 48 \\
\hline \multirow{4}{*}{ Age } & 19 years & 1 & 5 \\
& 20 years & 5 & 24 \\
& 21 years & 11 & 52 \\
& 23 years & 1 & 5 \\
& 25 years & 3 & 14 \\
\hline \multirow{5}{*}{ Social } & Student & 21 & 81 \\
& Employee - part time & 5 & 19 \\
& job & & \\
& Employee - full time & 0 & 0 \\
& job & 0 & 0 \\
& Self-employed & 0 & 0 \\
\hline \multirow{5}{*}{ Region } & Unemployee & 0 & 0 \\
& Bratislavský & 2 & 10 \\
& Trnavský & 14 & 67 \\
& Nitriansky & 2 & 9 \\
& Trenčiansky & 2 & 9 \\
& Zilinský & 1 & 5 \\
& Banskobystrický & 0 & 0 \\
& Prešovský & 0 & 0 \\
\hline
\end{tabular}


10 men (48\%) were among the total sample of the respondents. Regarding the age of the participants, 5\% were 19 years old, $24 \%$ were 20 years old, $52 \%$ were at the age of $21.5 \%$ at the age of 23 , and $14 \%$ were 25 years old. Most of the participants were students (81\%) and then $19 \%$ (5 respondents) employed in part-time. The majority of the respondents $(67 \%)$ came from the Nitriansky region, then Trnavský (10\%), Trenčiansky (9\%) and the Žilinský region (9\%) and only 1 respondent (5\%) lived in the Banskobystrický region.

\section{Statistic analysis}

For processing and evaluating eye-tracking research, the Gazepoint Analysis UX Edition software - version 3.1.0 (Gazepoint Canada) and Microsoft Excel were used. Timing for switching individual slides was set to 15 seconds. For the statistical data analysis, inductive statistics was selected, namely the Kruskal-Wallis test and Spearman's non-parametric test. The statistical processing was carried out in R version 3.5.1 (R Core Team (2017)). $\mathrm{R}$ : A language and environment for statistical computing. R Foundation for Statistical Computing, Vienna, Austria (R Foundation, 2017).

\section{RESULTS AND DISCUSSION}

As the testing was conducted in laboratory conditions through graphic visuals on which 3 wines were displayed at the same time, the detection of the actual perception of individual attributes was preceded by a test, which verified whether it depends where the product (wine) is located in the picture (right, centre, left) in order to find out the influence of the respondents. Based on the data derived from an eye camera (Time to first view in (ms)), the Kruskal-Wallis test, which is a non-parametric one-way anova, it was discovered that there is no difference $(p=0.44)$ in tracking wines based on location in the image stimulus (whether it is located on the right, left or centre).

The correlation between all dates of individual wines viewing time, measured using the Spearman's nonparametric coefficient, represents a value $(-0.77)$, which is a strong negative dependence, which means that the more people watch the wines on the left, the more time raises the other two wines (centre and right), respectively, when they look at the first wine on the left, other wines have a longer viewed time (Viewed Time in (s)).

In the questionnaire, a Likert's five-point scale, ranging from 'completely agree' (1) to 'completely disagree' (5) with influence of factor, was used for the identification of the key factors influencing conscious decision-making of Generation $\mathrm{Y}$ on the wine market. Based on the answers of the Generation $Y$ respondents recorded in the questionnaire and the relative calculated score, label and data associated with it (e.g. brand, variety, quality class etc.) appear to be the most important factor influencing the wine selection. According to the answers and the score achieved, bottle shape (16) and bottle colour (-8) are the least important factors, as can be seen in Figure 1.

The finding that the label is the most important factor when choosing white wine is also confirmed by the measuring through an eye camera. Based on the eyetracking curves (fixation points), it is possible to see in Figure 2 that the primary views led precisely to the label. This fact is also confirmed by the areas of interest in Table 2, where the lowest value $(1.69 \mathrm{~ms})$ is based on elapsed time to the first fixation (view) and the calculated median.

Similarly, in the case of the length of time spent (Table 3 ), it can be stated that the longest visual attention based on the measured median values happened in the case of a label (3.19 s). Contrary to the answers of the questionnaire, the fact is that the probands were more interested in bottle shape/colour compared to 'price', or 'discount'. The median of elapsed time when they were tracking bottle shape/colour is $1.94 \mathrm{~ms}$, while for prices it is up to $5.36 \mathrm{~ms}$. In terms of time spent, bottle shape/colour even represented the longest viewed attribute (3.63 s), as can be seen in Table 3.

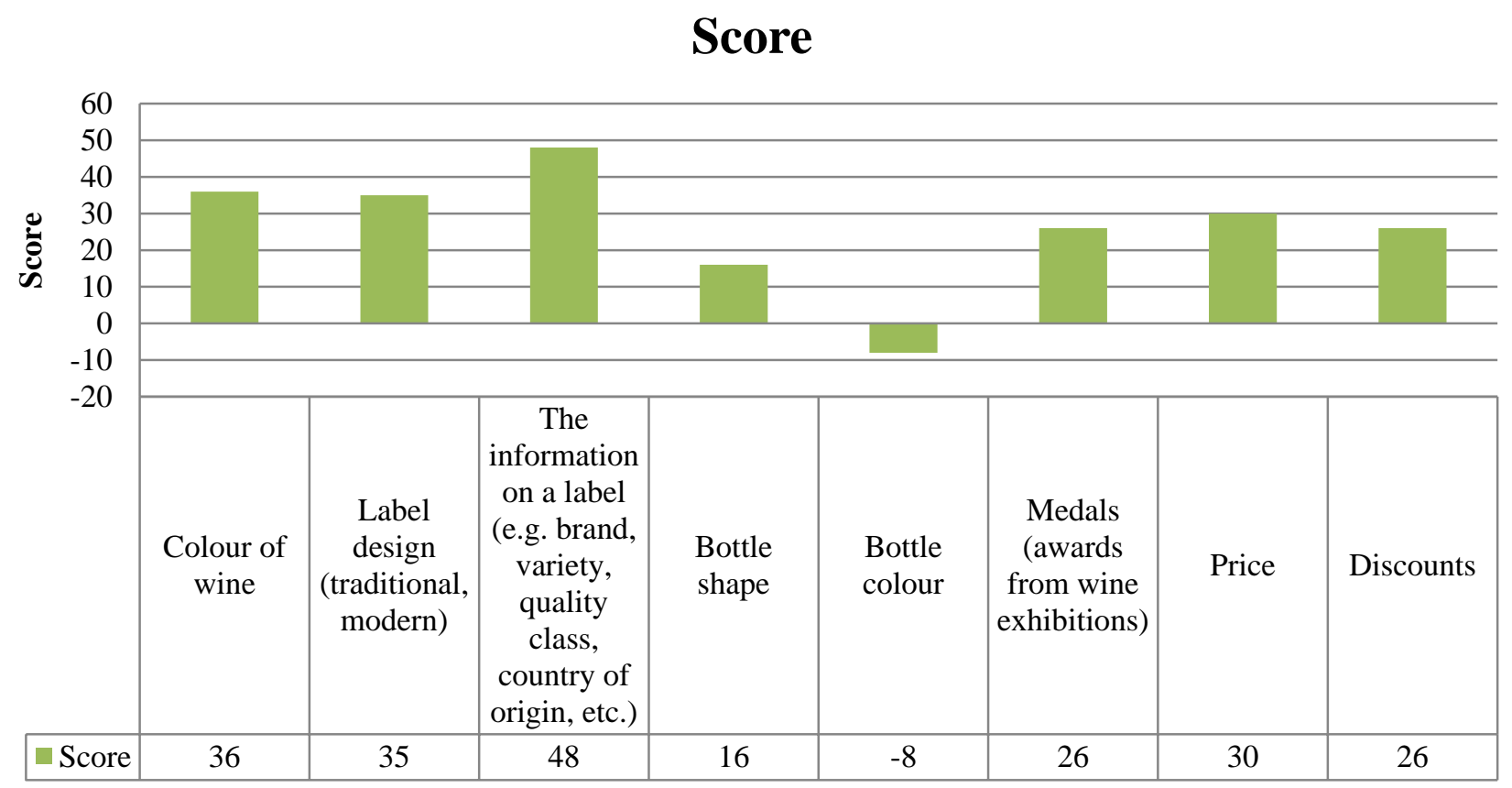

Figure 1 Factors Influencing the Bottled Wine Selection of Generation Y. 


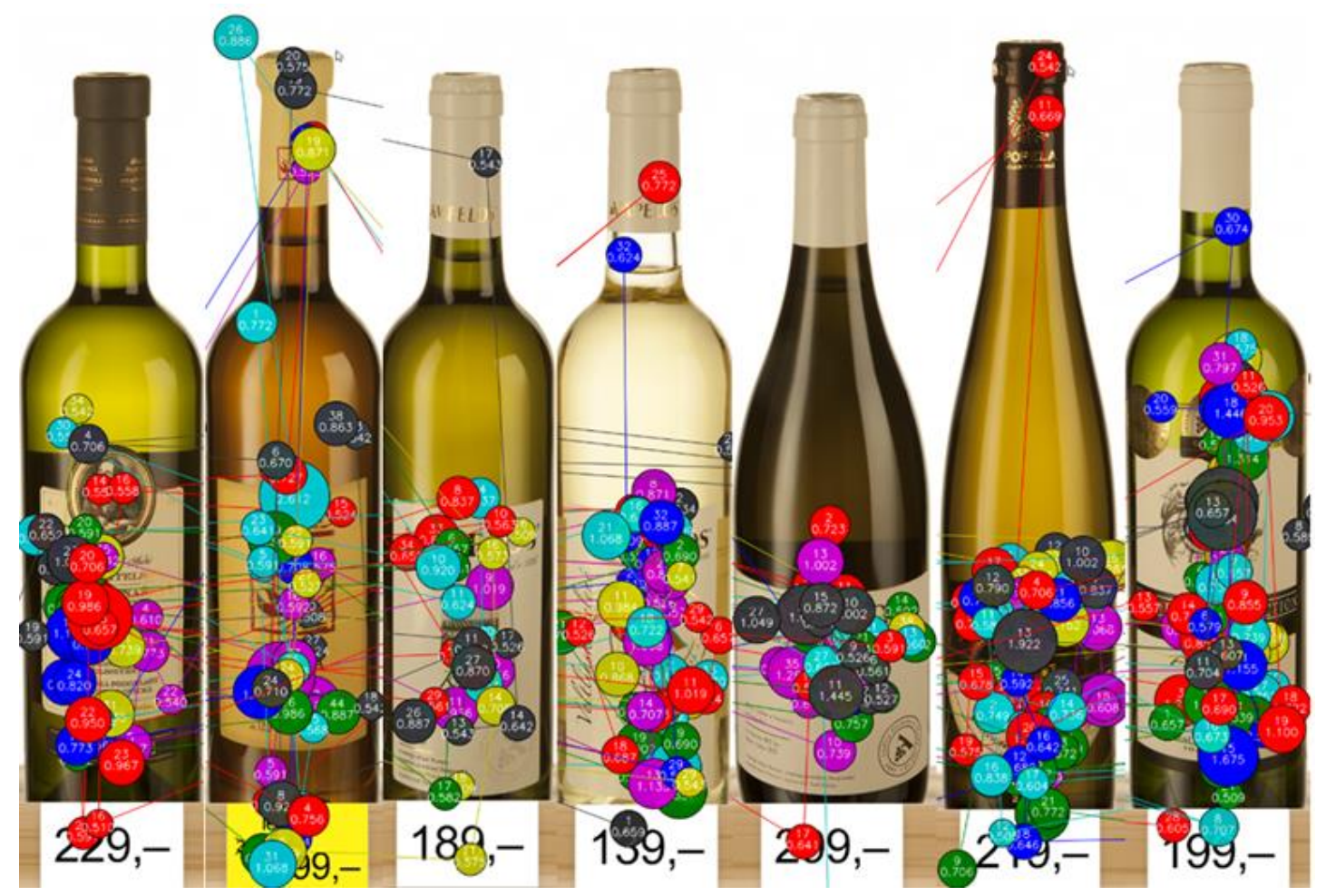

Figure 2 Eye-tracking Curves of Tested White Wine Visuals.

Table 2 Comparison of Perception of Individual Attributes Based on Areas of Interest (AOI) - Time to First Fixation (ms).

\begin{tabular}{lccc}
\hline \multicolumn{1}{c}{ Product } & Time to first view & & \\
\hline & Label & Bottle shape/colour & Price/Discount \\
\hline Šlechtitelská stanice vinařská Velké Pavlovice & 2.77 & 2.69 & 5.36 \\
Vinařství Gréger & 0.87 & 0.36 & 4.10 \\
Vinařství Ampelos (green bottle, classic) & 3.69 & 3.12 & 6.61 \\
Vinařství Ampelos (white bottle, classic) & 0.90 & 0.69 & 4.39 \\
Vinařství Ampelos (gray-green bottle, modern) & 1.44 & 1.10 & 5.57 \\
Vinařství Popela & 1.69 & 2.18 & 4.15 \\
Vinex & 2.23 & 1.94 & 7.71 \\
Average & $\mathbf{1 . 9 4}$ & $\mathbf{1 . 7 3}$ & $\mathbf{5 . 4 1}$ \\
Median & $\mathbf{1 . 6 9}$ & $\mathbf{1 . 9 4}$ & $\mathbf{5 . 3 6}$ \\
\hline
\end{tabular}

Table 3 Comparison of Perception of Individual Attributes Based on Areas of Interest (AOI) - Viewed Time (s).

\begin{tabular}{lrrr}
\hline \multicolumn{1}{c}{ Product } & Viewed Time (s) & & \\
\hline & Label & Bottle shape/colour & Price/Discount \\
\hline Šlechtitelská stanice vinařská Velké Pavlovice & 2.81 & 3.39 & 0.33 \\
Vinařství Gréger & 2.42 & 3.63 & 0.61 \\
Vinařství Ampelos (green bottle, classic) & 1.53 & 2.20 & 0.25 \\
Vinařství Ampelos (white bottle, classic) & 3.74 & 4.21 & 0.39 \\
Vinařství Ampelos (gray-green bottle, modern) & 3.19 & 3.53 & 0.39 \\
Vinařství Popela & 3.55 & 4.14 & 0.58 \\
Vinex & 5.11 & 5.58 & 0.27 \\
Average & $\mathbf{3 . 1 9}$ & $\mathbf{3 . 8 1}$ & $\mathbf{0 . 4 0}$ \\
Median & $\mathbf{3 . 1 9}$ & $\mathbf{3 . 6 3}$ & $\mathbf{0 . 3 9}$ \\
\hline
\end{tabular}




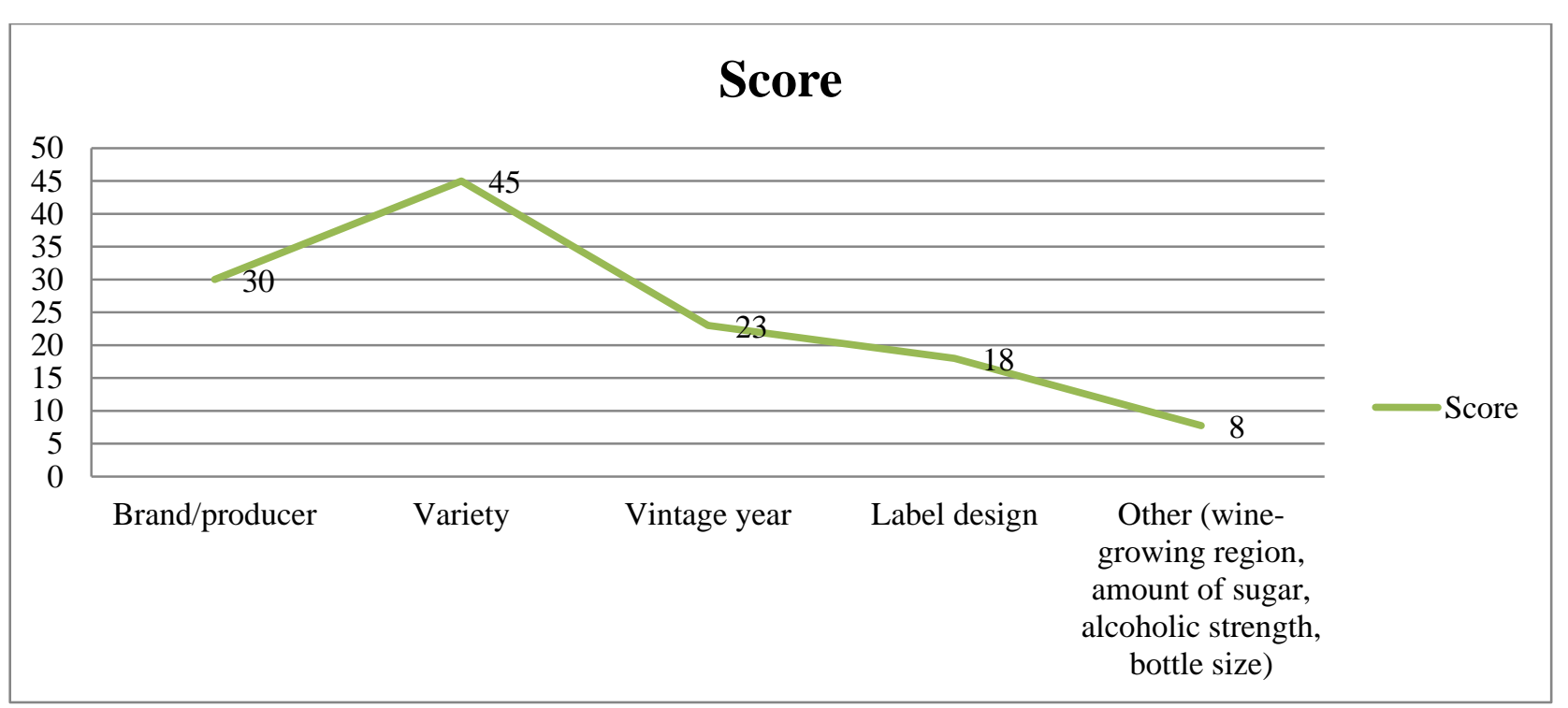

Figure 3 Importance of the Information on a Label Based on the Questionnaire Survey.

Based on conscious feedback (Figure 3) and the calculated score (45), indication of variety (e.g. Grüner Veltliner) is the most important information on a wine label. On the other hand, according to the respondents' answers, data such as a wine-growing region, the amount of sugar, alcohol, and bottle size (the 'other' option) are the least important.

However, in terms of visual attention and overall time spent, they were interested in the whole label design, in which they spent up to $3.585 \mathrm{~s}$ based on the measured median values. In this context, up to $76 \%$ of the respondents say that they prefer the traditional look of the label (motives of grapes, the grapevine or other wine theme) compared to the modern ones (geometric patterns, spirals, and non-traditional colours). Variety and vintage year interested the respondents only $1.140 \mathrm{~s}$ based on the median, which is $0.435 \mathrm{~s}$ less than brand. Based on the time spent, it can be said that consumer was most interested in total label design, brand and then variety or vintage year (Table 4). This fact and the difference over conscious feedback (variety was the most important) could also be caused by the fact that it was not a real choice and consumers saw the stimuli only in visual form.
Regarding bottle shape, the Generation Y respondents reported the most Bordeaux type of a bottle (62\%) in the questionnaire (see Figure 4), which is often used primarily for red wine. A minor part of the respondents (5\%) preferred Burgunder type (a bottle which is smaller and a little dumpy with dent), which is used all over the world for white and red wine. Based on the measurement of

\section{Which basic bottle shape do you prefer?}

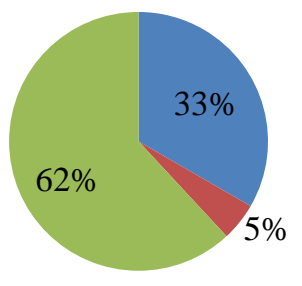

- Schlegel

Burgunder

Bordeaux
Figure 4 Wine Bottle Preference Based on the Questionnaire Survey.

Table 4 Comparison of Perception of the Information on a Label through Areas of Interest (AOI) - Viewed Time (s).

\begin{tabular}{|c|c|c|c|c|c|c|c|c|}
\hline $\begin{array}{l}\text { Product/ } \\
\text { attribute }\end{array}$ & $\begin{array}{c}\text { Šlechtitelská } \\
\text { stanice } \\
\text { vinařská } \\
\text { Velké } \\
\text { Pavlovice }\end{array}$ & $\begin{array}{c}\text { Vinařství } \\
\text { Gréger }\end{array}$ & $\begin{array}{l}\text { Vinařství } \\
\text { Ampelos } \\
\text { (green } \\
\text { bottle, } \\
\text { classic) }\end{array}$ & $\begin{array}{c}\text { Vinařství } \\
\text { Ampelos } \\
\text { (white } \\
\text { bottle, } \\
\text { classic) }\end{array}$ & $\begin{array}{c}\text { Vinařství } \\
\text { Ampelos } \\
\text { (gray- } \\
\text { green } \\
\text { bottle, } \\
\text { modern) }\end{array}$ & $\begin{array}{c}\text { Vinařství } \\
\text { Popela }\end{array}$ & Vinex & Median \\
\hline $\begin{array}{l}\text { Variety } \\
\text { and } \\
\text { vintage } \\
\text { year }\end{array}$ & 1.21 & 0.99 & 0.53 & 1.07 & 1.22 & 1.91 & 1.49 & 1.140 \\
\hline Brand & 1.68 & 1.33 & 1.25 & 1.47 & 2.21 & 1.94 & 2.66 & 1.575 \\
\hline Price & 0.63 & 0.23 & 0.29 & 0.39 & 0.38 & 0.40 & 0.25 & 0.385 \\
\hline $\begin{array}{l}\text { Label } \\
\text { design }\end{array}$ & 3.33 & 3.59 & 1.97 & 4.32 & 3.60 & 4.25 & 5.60 & 3.595 \\
\hline $\begin{array}{l}\text { Bottle } \\
\text { cap }\end{array}$ & 0.27 & 0.57 & 0.28 & 0.49 & 0.35 & 0.40 & 0.26 & 0.375 \\
\hline
\end{tabular}


visual attention through an eye camera, it is possible to say that wines from brands such as Vinařství Ampelos (Time to first fixation $0.53 \mathrm{~ms}$ ), Šlechtitelská stanice vinařská Velké Pavlovice (Time to first fixation $0.63 \mathrm{~ms}$ ), Vinařství Gréger (Time to first fixation $0.99 \mathrm{~ms}$ ), which are filled in Bordeaux type of bottles, attracted the majority of attendants' attention.

\section{CONCLUSION}

The submitted paper is focused on the examination of the factors influencing the selection of white wines, by means of a questionnaire survey and biometric method - eyetracking. The most important factor influencing decisionmaking of Generation $\mathrm{Y}$ can be considered a wine label based on the results of the performed test. In the real selection, it is possible to assume that the most important factor would be price, or discount, that was greatly ignored in this case, because it was not a real scenario. In the case of a detailed examination of the information on a label, differences between the respondents' answers and real visual attention were noted. While the participants considered variety, or vintage year as the most important factors, on the other hand, on the basis of the answers of the questionnaire, they were most concentrated on label design and subsequently on the brand of the wine on the basis of visual attention. In the case of bottle preferences in which wine is stored, the respondents' answers also coincided with their real attention in terms of primary attracting. Despite some weaknesses, this test shows that the use of an eye camera when examining the factors influencing consumer choice has a great potential because it can provide a new view of the decision-making process based on real data.

In the future, it is planned to carry out similar research using a mobile eye camera to realize the test with real wine bottles. It is also assumed that engaging of other methods will be possible (e.g. biometric methods of recognizing micro-emotions based on facial expressions - Facereading) in order to obtain information about real attention of the tested probands due to the individual attributes that influence their selection. Based on the statistical tests, it was found out that wine to which the respondents look at first has the least viewed time compared to the other two wines, and so it would be good to use a balancing block, such as Latin squares, to prevent this effect, which should be a subject for further experiments. Latin squares are one of the CRBD systems (Complete Randomized Block Design). The first evaluator gets the $\mathrm{ABC}$ order, the second $\mathrm{BCA}$, the third $\mathrm{CAB}$ (Williams Latin square).

\section{REFERENCES}

Anchor, J. R., Lacinová, T. 2015. Czech wine consumers: maturing with age?. E+M Ekonomie a Management, vol. 18, no. 1, p. 169-182. https://doi.org/10.15240/tul/001/2015-1$\underline{013}$

Artero, A., Artero, A., Tarín, J. J., Cano, A. 2015. Impact of moderate wine consumption on health. Maturitas, vol. 80, no. 1, p. 3-13. https://doi.org/10.1016/j.maturitas.2014.09.007

Babin, B. J., Harris, E. G. 2016. CB: Consumer Behavior. $7^{\text {th }}$ ed. Boston, USA : Cengage Learning, 390 p. ISBN 978-1305-40322-2.

Berčík, J., Nagyová, L., Horská, E. 2016. Využitie neuromarketingu $v$ retailingu a vizuálnom merchandisingu potravín. $1^{\text {st }}$ ed. Nitra : Slovenská pol’nohospodárska univerzita v Nitre. 138 p. ISBN 978-80-552-1613-3.

Bergh, J. V., Behrer, M. 2016. How cool brands stay hot: Branding to generation $Y$ and Z. $3^{\text {rd }}$ ed. London, UK : KoganPage. 287 p. ISBN 978-0-7494-7717-2.

Brunner, T. A., Siegrist, M. 2011. A consumer-oriented segmentation study in the Swiss wine market. British Food Journal, vol. 113, no. 3, p. 353-373. https://doi.org/10.1108/00070701111116437

de Magistris, T., Groot, E., Gracia, A., Albisu, L. M. 2011. Do Millennial generation's wine preferences of the "New World" differ from the "Old World"?: A pilot study. International Journal of Wine Business Research, vol. 23, no. 2, p. 145-160. https://doi.org/10.1108/17511061111143007

Dlačić, J., Kadić-Maglajlić, S. 2013. The Role of Gender and Situational Factors in Wine Consumption of Generation Y. South East European Journal of Economics and Business, vol. 8, no. 1, p. 53-61. https://doi.org/10.2478/jeb-2013-0008

Elliot, S., Barth, J. E. 2012. Wine label design and personality preferences of millennials. Journal of Product \& Brand Management, vol. 21, no. 3, p. 183-191. https://doi.org/10.1108/10610421211228801

Fountain, J., Lamb, C. 2011. Generation Y as young wine consumers in New Zealand: how do they differ from Generation X?. International Journal of Wine Business Research, vol. 23, no. 2, p. 107-124. https://doi.org/10.1108/17511061111142981

Hall, J., Binney, W., Omahony, G. B. 2004. Age Related Motivational Segmentation of Wine Consumption in a Hospitality Setting. International Journal of Wine Marketing, vol. 16, no. 3, p. 29-43. https://doi.org/10.1108/eb008777

Hristov, H., Kuhar, A. 2015. Subjective knowledge as a determinant of young adult consumers wine behaviour. British Food Journal, vol. 117, no. 12, p. 2930-2946. https://doi.org/10.1108/BFJ-04-2015-0163

Charters, S., Velikova, N., Ritchie, C., Fountain, J., Thach, L., Dodd, T. H., Fish, N., Herbst, F., Terblanche, N. 2011. Generation $\mathrm{Y}$ and sparkling wines. International Journal of Wine Business Research, vol. 23, no. 2, p. 161-175. https://doi.org/10.1108/17511061111143016

Chrysochou, P., Krystallis, A., Mocanu, A., Lewis, R. L. 2012. Generation Y preferences for wine. British Food Journal, vol. 114, no. 4, p. 516-528. https://doi.org/10.1108/00070701211219531

Lategan, B. W., Pentz, C. D., Preez, R. D. 2017. Importance of wine attributes: a South African Generation Y perspective. British Food Journal, vol. 119, no. 7, p. 1536-1546. https://doi.org/10.1108/BFJ-09-2016-0420

Lockshin, L., Corsi, A. M. 2012. Consumer behaviour for wine 2.0: A review since 2003 and future directions. Wine Economics and Policy, vol. 1, no. 1, p. 2-23. https://doi.org/10.1016/j.wep.2012.11.003

Marinelli, N., Fabbrizzi, S., Sottini, V. A., Sacchelli, S., Bernetti, I., Menghini, S. 2014. Generation Y, wine and alcohol. A semantic differential approach to consumption analysis in Tuscany. Appetite, vol. 75, p. 117-127. https://doi.org/10.1016/j.appet.2013.12.013

Meravá, E. 2017. Vinič hroznorodý, hroznové víno: Situačná a výhl'adová správa k 31. 7. 2017 (Grapevine, grapes wine: Situation and outlook report to the $31^{\text {st }}$ July 2017). Available

at: http://www.vuepp.sk/dokumenty/komodity/2017/Vino17.pdf

Morin, C. 2011. Neuromarketing: The New Science of Consumer Behavior. Society, vol. 48 no. 2, p. 131-135. https://doi.org/10.1007/s12115-010-9408-1 
Mueller, S., Remaud, H., Chabin, Y. 2011. How strong and generalisable is the Generation Y effect? A cross-cultural study for wine. International Journal of Wine Business Research, vol. 23, no. 2, p. 125-144. https://doi.org/10.1108/17511061111142990

Noble, S. M., Haytko, D. L., Phillips, J. 2009. What drives college-age Generation Y consumers? Journal of Business $\begin{array}{lllll}\text { Research, vol. 62, no. 6, p. 617-628. } & \end{array}$ https://doi:10.1016/j.jbusres.2008.01.020

OIV. 2017. State of the Vitivini culture World Market. Available at: http://www.oiv.int/public/medias/5287/oivnoteconjmars2017-en.pdf

$\mathrm{R}$ Foundation, 2017. The $\mathrm{R}$ Project for Statistical Computing. Available at: https://www.R-project.org

Ramsøy, T. Z. 2015. Introduction to Neuromarketing \& Consumer Neuroscience. $1^{\text {st }}$ ed. Rørvig : Neurons. 204 p. ISBN 978-8799760206.

Regulation No 313/2009 on viticulture and wine of 30 June 2009 of the codex of Slovak Republic

Roe, D., Bruwer, J. 2017, Self-concept, product involvement and consumption occasions. British Food Journal, vol. 119, no. 6, p. 1362-1377. https://doi.org/10.1108/BFJ-10-2016-0476

Sethna, Z., Blythe, J. 2016. Consumer behaviour. $3^{\text {rd }}$ ed. Los Angeles, USA : Sage. 528 p. ISBN 978-1473919136.

Schiffman, L. G., Wisenblit, J. 2015. Consumer Behavior. $11^{\text {th }}$ ed. Harlow : Pearson Education. 492 p. ISBN 978-0-27378713-6.

Stanciu, S., Neagu, T. 2014. The Factors Influencing Consumers' Behaviour on Wine Consumption in the Moldovan Wine Market. Risk in Contemporary Economy, vol. 1 , no. 1, p. 406-418.

Szmigin, I., Piacentini, M. 2015. Consumer behaviour. $1^{\text {st }}$ ed. Oxford : Oxford University Press. 444 p. ISBN 978-0-19964644-9.

Šamánek, M., Urbanová, Z. 2013. Když víno léči. $1^{\text {st }}$ ed. Praha : Galén. 124 p. ISBN 9788072629725.

Tariba, B. 2011. Metals in Wine-Impact on Wine Quality and Health Outcomes. Biological Trace Element Research, vol. 144, no. 1-3, p. 143-156. https://doi.org/10.1007/s12011011-9052-7

Thach, E. C., Olsen, J. E. 2006. Market segment analysis to target young adult wine drinkers. Agribusiness, vol. 22, no. 3, p. 307-322. https://doi.org/10.1002/agr.20088

Tomek, G., Vávrová, V. 2011. Marketing od myšlenky $k$ realizaci. $3^{\text {rd }}$ ed. Praha : Professional Publishing. 344 p. ISBN 978-80-7431-042-3.

Velčovská, Š. 2018. Generation Y's Perception of Product Origin and its Labelling in the Context of Food Quality and Safety. Amfiteatru Economic, vol. 20, no. 47, p. 46-61. https://doi.org/10.24818/EA/2018/47/46

Veselá, J., Zich, R. 2015. The Country-of-Origin Effect and its Influence on Consumer's Purchasing Decision. Acta Universitatis Agriculturae et Silviculturae Mendelianae Brunensis, vol. 63, no. 2, p. 667-673. https://doi.org/10.11118/actaun201563020667

\section{Acknowledgments:}

This paper was written with support from the Internal Grant Agency of FaME TBU No. IGA/FaME/2016/009 'The Use of New Marketing Trends for Increasing of Companies' Performance in Selected Areas of Economy'.

\section{Contact address:}

*Jana Němcová, Tomas Bata University in Zlín, Faculty of Management and Economics, Department of Management and Marketing, Mostní 5139, 76001 Zlín, Czech Republic, Tel.: +420721406327, E-mail: jnemcova@utb.cz

Jakub Berčík, Slovak University of Agriculture in Nitra, Faculty of Economics and Management, Department of Marketing and Trade, Tr. A. Hlinku 2, 94976 Nitra, Slovak Republic, Tel.: +421376414145, E-mail: jakub.bercik@uniag.sk

Corresponding author: * 